\title{
Complex mineralization of cell material via diagenesis
}

\author{
MÁRTA POLGÁRI ${ }^{1,2}$, ILDIKÓ GYOLLAI ${ }^{1}$
}

${ }^{1}$ RCAES, Institute for Geological and Geochemical Research (rodokrozit@gmail.com; gyildi@gmail.com)

${ }^{2}$ Eszterházy University (rodokrozit@gmail.com)

The role of biogenicity in mineral world is predicated on the observation that biological processes interact with physical and chemical processes at and near the Earth's surface, mentioning interaction of geospheres. The increase of oxygen level started by activity of cyanobacteria and basically changed the environment offering opportunity of existence of high valence forms of elements. Microbially mediated minerals are very fine-grained, and microbial processes are very efficient comparing to chemical processes. Variable rocks and sedimentary $\mathrm{Fe}, \mathrm{Mn}$ ores formed by microbial metabolism, redox change of elements, and complex diagenetic mineralization of cell material and extracellular polymeric substance (EPS). Microbially mediated processes, the role of cell metabolism and EPS is very important in syngenetic mineralization, represent also considerable element source reservoir in the form of bond cations and anions releasing via diagenesis. These are very effective factors influencing the syn- and diagenetic mineralization processes. They offer bioessential elements among others Fe, $\mathrm{Mn}, \mathrm{Zn}, \mathrm{P}, \mathrm{Cu}, \mathrm{As}, \mathrm{Cu}, \mathrm{Ni}, \mathrm{Se}, \mathrm{Mo}, \mathrm{Co}, \mathrm{REE}$ - which bond as ions in $3 \mathrm{D}$ structure of proteins. The microbial mats form giant mass of sedimentary ores including selective element enrichment of $\mathrm{Fe}, \mathrm{Mn}, \mathrm{Si}, \mathrm{Mg}, \mathrm{P}$, As and Ce. The microbes survive extreme conditions (hyperthermophile, extremophile organisms). Microbial mats and other biosignatures can be used as indicators. Mechanisms in the background of element enrichments are variable: direct oxidation of main ore forming metals including trace elements ( $\mathrm{Fe}, \mathrm{Mn}, \mathrm{Co}, \mathrm{Ce}$ ); structure (mineral) stabilizing role $(\mathrm{Mg})$; adsorption $(\mathrm{Ni}$ in $\mathrm{MnOOH}$ structures); detoxication (Ce(III) to $\mathrm{Ce}(\mathrm{IV})$ by $\mathrm{Mn}$ oxidizing microbes on $\mathrm{MnOOH}$ microbial oxidation path with $\mathrm{P}$ ); vitamin demand (Co for vitamin B); enzymatic demand; protection against UV radiation and high element concentrations ( $\mathrm{Fe}$ concentration - $\mathrm{Si}$ ); energy aspects; etc. After death of cells the decomposition of cells and EPS starts and ions, which bound on their surface, will liberalize and a complex transforming mineralization starts, which can result quartz, mixed carbonates, feldspar, pyroxene, hornblende, clay minerals, apatite, sulfides, sulfates, etc., depending on the geochemical conditions. These poorly crystallized minerals can form more stable minerals on time. 